\title{
A new thrombospondin-related anonymous protein homologue in Neospora caninum (NcMIC2-like1)
}

\author{
L. M. PEREIRA ${ }^{1}$, J. A. CANDIDO-SILVA ${ }^{1}$, E. DE VRIES $^{2}$ and A. P. YATSUDA ${ }^{1}$ \\ ${ }^{1}$ Faculdade de Ciências Farmacêuticas de Ribeirão Preto, Universidade de São Paulo, Av do Café, sn/n, 14040-903, \\ Ribeirão Preto, SP, Brazil \\ ${ }^{2}$ Division of Parasitology and Tropical Veterinary Medicine, Department of Infectious Diseases and Immunology, \\ Utrecht University, P.O. Box 80165, 3508 TD, Utrecht, The Netherlands
}

(Received 29 fanuary 2010; revised 2 Fune, 29 fune and 4 August 2010; accepted 9 August 2010; first published online 30 September 2010)

SUMMARY

Neospora caninum is an Apicomplexan protozoan that has the dog as a definitive host and cattle (among other animals) as intermediate hosts. It causes encephalopathy in dogs and abortion in cows, with significant loss in worldwide livestock. As any Apicomplexan, the parasite invades the cells using proteins contained in the phylum-specific organelles, like the micronemes, rhoptries and dense granules. The aim of this study was the characterization of a homologue (denominated NcMIC2-like1) of N. caninum thrombospondin-related anonymous protein (NcMIC2), a micronemal protein previously shown to be involved in the attachment and connection with the intracellular motor responsible for the active process of invasion. A polyclonal antiserum raised against the recombinant NcMIC2-like1 functional core (thrombospondin and integrin domains) recognized the native form of $\mathrm{NcMIC} 2$-like1, inhibited the in vitro invasion process and localized NcMIC2-like1 at the apical complex of the parasite by confocal immunofluorescence, indicating its micronemal localization. The new molecule, NcMIC2-like1, has features that differentiates it from NcMIC2 in a substantial way to be considered a homologuet.

Key words: Neospora caninum, Apicomplexa, thrombospondin-related anonymous protein, microneme, invasion assay, TRAP, MIC2-like1, MIC2.

\section{INTRODUCTION}

Neospora caninum is an Apicomplexan protozoan that was isolated in 1988 by Dubey and collaborators when investigating the origin of a severe neuromuscular disorder in dogs. The disease was first described in dogs in 1984, in sheep in 1987 and was correlated to economical losses in cattle in 1988 (Dubey et al. 1988). Due to morphological and biochemical similarities between N. caninum and Toxoplasma gondii, and the fact that both life cycles involve 2 types of host with similar kinetics, the first cases of neosporosis could have been misdiagnosed as toxoplasmosis (Hemphill et al. 2006). N. caninum has been detected in definitive and/or intermediate hosts in almost all continents (Dubey et al. 2007), and it is now known that dogs and coyotes are definitive hosts and cattle are economically the most relevant intermediate hosts.

* Corresponding author: Departamento de Análises Clínicas, Bromatológicas e Toxicológicas, Faculdade de Ciências Farmacêuticas de Ribeirão Preto, Universidade de São Paulo, Ribeirão Preto, 14040-903, Brazil. Tel: +55163602 4724. Fax: 1636024725. E-mail: ayatsuda@ fcfrp.usp.br

$\uparrow$ Nucleotide sequence data reported in this paper are available in the GenBank ${ }^{\mathrm{TM}}$ under the Accession number HQ011383.
As all other Apicomplexa, N. caninum is an obligatory intracellular parasite and invades the host cells by a conserved and extremely successful mechanism. The host cell invasion process occurs via a parasite-driven mechanism known to be an active invasion (Cesbron-Delauw et al. 2008), requiring the use of its own actin/myosin motor-system (Daher and Soldati-Favre, 2009). The multi-factorial process of invasion involves receptors related to the recognition, gliding and invasion. Receptors are constituted by a set of proteins released by micronemes, rhoptries and dense granules. Micronemes are organelles containing a concentrated mixture of adhesive proteins released to enable parasite invasion (Friedrich et al. 2010). They possess modules homologous to adhesive domains of higher eukaryotes that have been demonstrated to act in the direct binding to host cells (DiCristina et al. 2000). These motifs are present in one or multiple copies in micronemal proteins and a large number of combinations of these blocks have been described, making each micronemal protein structurally unique, which increases their invasion capacity (Soldati et al. 2001).

Among Apicomplexans, a highly conserved family of microneme proteins is the thrombospondinrelated anonymous protein (TRAP). A range of different denominations have been described, there are members of TRAP in Plasmodium sporozoite 
(TRAP) and ookinete (CTRP), T. gondii (TgMIC2) (Sultan et al. 1997; Wan et al. 1997; Dessens et al. 1999; Menard, 2000; Huynh et al. 2004), B. bovis (BbTRAP, Gaffar et al. 2004a), Eimeria (EtMIC1, Tomley et al. 2001), N. caninum (NcMIC2, Lovett et al. 2000) and Cryptosporidium parvum (CpMIC 1, Putignani et al. 2008). All members of the TRAP family in Apicomplexa are type I transmembrane proteins which have a variable number of 2 adhesive extracellular domains: (i) integrin I domain or von Willebrand factor (vWFa) A domain and (ii) thrombospondin type I (TSR or TSP-1), followed by a transmembrane domain and a cytoplasmic tail (Starnes et al. 2006).

In $N$. caninum, 5 micronemal proteins have been described, NcMIC1, NcMIC2, NcMIC3, NcMIC4 and NcMIC10 (Sonda et al. 2000; Lovett et al. 2000; Hoffet al. 2001; Naguleswaran et al. 2002; Keller et al. 2002). Preliminary analysis of ESTs from N. caninum indicated the presence of a second potential protein TRAP, besides the previously described NcMIC2 (Lovett et al. 2000), which we designated as NcMIC2like1. The presence of a second TRAP in N. caninum represents a unique fact for coccidia, including Eimeria, Toxoplasma, Sarcocystis and Cryptosporidium. Although the whole genome of $T$. gondii has been sequenced (Aurrecoechea et al. 2010), several investigations have unsuccessfully searched for other members of TRAP in T. gondii. Therefore, we decided to investigate NcMIC2-like1.

MATERIALS AND METHODS

\section{Tissue culture and parasite purification}

Vero cell cultures were maintained in RPMI-1640 medium (LGC Biotechnology) supplemented with $5 \%$ fetal calf serum (Cultilab), $2.05 \mathrm{~mm}$ glutamine, $50 \mathrm{U}$ of penicillin/streptomycin at $37^{\circ} \mathrm{C}$ and $5 \% \mathrm{CO}_{2}$ in T-25 $\mathrm{cm}^{2}$ or $75 \mathrm{~cm}^{2}$ tissue-culture flasks. Cultures were trypsinized at least once a week. $N$. caninum tachyzoites of the $\mathrm{Nc}-1$ isolate were maintained in Vero-cell monolayers and the excess Vero cell debris was removed by exclusion chromatography in Sephadex G-25 (PD-10 columns, GE). The recovered parasites were counted in a Neubauer chamber after adequate dilution and the average recovery on $25 \mathrm{~cm}^{2}$ culture was $1 \times 10^{7}$ tachyzoites, yielding around $95 \%$ tachyzoite purification.

\section{Determination of the full length NcMIC2-like1 cDNA sequence}

The RNA ligase-mediated rapid amplification (RACE) of 5' (primer Race 5'; CGACTGGAGCACGAGGACACTGA) and 3' (primer Racer 3'; GCTGTCAACGATACGCTACGTAACG) cDNA ends (RLM-RACE, Gene Racer kit Invitrogen) was initially used, based on information of partial
ESTs of NcMIC2-like1 available by that time (e.g. CF273823, CF261023, CF598400). The RACE PCR generated approximately $99 \cdot 7 \%$ of the NcMIC2-like1 protein sequence. The non-annotated genomic database from $N$. caninum (www.sanger.ac.uk/cgi-bin/ blast/submitblast/n_caninum) allowed the analysis of contigs flanking the NcMIC2-like1 gene region. Based on the Sanger nomenclature, the NcMIC2like1 sequence obtained by that time was at the contig 630, which was flanked by contig 8340. Therefore, one forward primer (GGGAGATTTGAGAAGAAGCGAGA) located at the contig 8340, and a reverse primer at the contig 630 ('TTTGGCGACGGGAATTACTATGG) were designed. After several PCRs and sequencing, the analyses indicated a contig between 8340 and 630, contig 1212, and it was possible to conclude that the complete NcMIC2like1 gene sequence was located at the 1212 and 630 contigs, which were recently all merged into a single contig 1051 (http://www.sanger.ac.uk/cgi-bin/blast/ getseq?id=n01DT Cy929480J7997P.1;db=yeastpub/ NEOS.contigs. fasta; $a c c=$ Contig1051).

\section{Expression of recombinant NcMIC2-like1 in E. coli} and generation of polyclonal antiserum

The NcMIC2-like1 open reading frame without the putative signal peptide was amplified by PCR from bases 138 (numbered from the first base of the initiation codon) to 1260 using the forward BamHI primer 5' CCCGGATCCCAGGCAGCGTCAAATGAA 3' and the reverse HindIII 5' CCCAAGCTTAGATCCTGACCGACTTC'T 3' (restriction sites are bold underlined). For expression, E. coli strain BL21 was transformed with pET28/NcMIC2-like1, and cultures incubated with or without $5 \mathrm{~mm}$ isopropyl$\beta$-D-thiogalactopyranoside (IP'TG). Bacterial pellets were sonicated first in $10 \mathrm{~mm}$ Tris buffer $(\mathrm{pH} \mathrm{7 \cdot 0)}$ followed by a sonication in $8 \mathrm{M}$ urea, run on $10 \%$ SDS-PAGE minigels and silver stained to confirm expression. Histidine-tagged purified recombinant pET28/NcMIC2-like1 protein (150-200 $\mu \mathrm{g} / \mathrm{shot})$ and tachyzoite protein extract (250-300 $\mu \mathrm{g} / \mathrm{shot}$ ), quantified by the Bradford method, were used to immunize 1 rabbit each (Kawasaki et al. 2007). The animals were immunized 3 times (3-week intervals) firstly with incomplete Freund's adjuvant and subsequently with complete Freund's adjuvant, generating a polyclonal antiserum against the fragment of NcMIC2-like1 (anti-NcMIC2-like1) and against tachyzoite protein extract.

\section{Neospora caninum tachyzoite protein extract and control}

The $N$. caninum tachyzoite protein extract and Vero protein extract (control) were obtained by lysis of the tachyzoites $\left(2 \times 10^{8}\right.$ per $\left.0.5 \mathrm{ml}\right)$ or the Vero cells 
$\left(5 \times 10^{6}\right.$ per $\left.0.5 \mathrm{ml}\right)$ in $7 \mathrm{M}$ urea, $2 \mathrm{M}$ thiourea, and $4 \%$ CHAPS (3-[(3-cholamidopropyl)-dimethylammonio]-1-propanesulfonate). The Vero control extracts (secreted and total protein) were made because we have previously observed that polyclonal antiserum cross-reacts with the cell source of the parasite (Gaffar et al. 2004a,b).

\section{Secreted fraction from Neospora caninum and control}

Freshly purified tachyzoites $\left(5 \times 10^{7}\right)$ in $1 \mathrm{ml}$ of RPMI were incubated for $10 \mathrm{~min}$ at $37^{\circ} \mathrm{C}$ and subsequently in ice for $10 \mathrm{~min}$, followed by mild centrifugation $\left(3000 \mathrm{~g}, 10 \mathrm{~min}, 4^{\circ} \mathrm{C}\right)$ to remove the tachyzoites. The supernatant was then centrifuged for $10 \mathrm{~min}$ at higher speed $\left(10000 \mathrm{~g}, 4^{\circ} \mathrm{C}\right)$ to remove residual insoluble components before TCA/acetone precipitation. Equal parts of RPMI protein content were incubated with $30 \%$ trichloroacetic acid (TCA), $50 \mathrm{~mm}$ dithiothreitol (DTT) in acetone for $40 \mathrm{~min}$ at $-20^{\circ} \mathrm{C}$ and centrifuged for $15 \mathrm{~min}, 10000 \mathrm{~g}$ at $4{ }^{\circ} \mathrm{C}$. The supernatant was discarded and the pellet was then washed with $10 \mathrm{~mm}$ DTT in acetone and centrifuged for $5 \mathrm{~min}, 10000 \mathrm{~g}$ at $4{ }^{\circ} \mathrm{C}$. The final pellet was dried at room temperature and dissolved in $7 \mathrm{M}$ urea, $2 \mathrm{M}$ thiourea and $4 \%$ CHAPS. The same procedure was performed with Vero cells as a control.

\section{One dimensional (1D) electrophoresis and $1 D$ Western blotting (WB)}

The purified NcMIC2-like1 recombinant fragment, tachyzoite protein extract, secreted fraction and respective Vero controls were separated by $10 \%$ SDS-PAGE and transferred to PVDF membrane (Immobilon ${ }^{\text {TM }}-\mathrm{P}$, Millipore). The blot was blocked with $0 \cdot 8 \%$ porcine gelatin (Sigma-Aldrich) diluted in phosphate-buffered saline (PBS) containing $0.5 \%$ Tween (PBST) for $1 \mathrm{~h}$ at $37^{\circ} \mathrm{C}$. Rabbit antisera were diluted in PBST containing $0 \cdot 2 \%$ porcine gelatin and incubated overnight at $4{ }^{\circ} \mathrm{C}$. The blot was washed with PBST and incubated with antirabbit-immunoglobulin conjugated to HRP (ZyMed-Invitrogen) for $1 \mathrm{~h}$ at $37^{\circ} \mathrm{C}$. After washing with PBST, the blot was developed with an enhanced chemiluminescent substrate for the detection of HRP (SuperSignal West Pico Chemiluminescent Substrate, Pierce). Images of the gels and blots were acquired with LabScan v5.0 software on a flatbed scanner (Image Scanner, GE).

\section{Two dimensional (2D) electrophoresis and $2 D$ Western blotting}

Tachyzoite protein extract $(50 \mu \mathrm{g})$ and secreted fraction $(\sim 25 \mu \mathrm{g})$ were dissolved in a rehydration solution containing $7 \mathrm{M}$ urea, $2 \mathrm{M}$ thiourea, 4\% CHAPS,
2\% carrier ampholyte mixture (pH 3-11 NL in Immobiline Drystrip gels, GE), 20 mu dithiothreitol (DTT) and supplemented with protease inhibitors (Protease Inhibitor cocktail, Sigma-Aldrich). The samples were loaded on $7 \mathrm{~cm}$ IPG strips ( $\mathrm{pH} 3-11$ NL), rehydrated and focused in an automated overnight run (IPGPhor ${ }^{\mathrm{TM}}$ ) using 10-14 h of rehydration, and a step voltage focusing procedure $(20 \mathrm{~min}$ $100 \mathrm{~V}, 30 \mathrm{~min} 300 \mathrm{~V}, 1 \cdot 2 \mathrm{~h} 1000 \mathrm{~V}, 15 \mathrm{~min} 5000 \mathrm{~V}$, followed by $5000 \mathrm{~V}$ until a total of $5 \mathrm{Kvh}$ was reached). Image acquisition was performed as described for one-dimensional gels/blots.

\section{Induction assays for microneme secretion}

Freshly purified tachyzoites were washed once with RPMI, pelleted ( $3000 \mathrm{~g}, 3 \mathrm{~min}$, room temperature) and re-suspended in RPMI $\left(2 \times 10^{8} \mathrm{ml}\right)$. To induce secretion, $50 \mu \mathrm{l}$ of tachyzoite suspension were added to $50 \mu \mathrm{l}$ of RPMI containing doubled drug concentrations (EtOH 1\%, DMSO 1\%, ionomycin $400 \mathrm{nM}$ or A23187 $400 \mathrm{~nm}$ ) and incubated for $2 \mathrm{~min}, 37^{\circ} \mathrm{C}$. To inhibit secretion, tachyzoites were pre-treated with $100 \mu \mathrm{M}$ BAPTA-AM at $18^{\circ} \mathrm{C}, 10 \mathrm{~min}$, then added to the drug solution and incubated for $2 \mathrm{~min}$ at $37^{\circ} \mathrm{C}$. The supernatant was collected by sequential centrifugation $(3000 \boldsymbol{g}, 10 \mathrm{~min}$ followed by $10000 \boldsymbol{g}$, $10 \mathrm{~min}$ ), applied in a $12 \cdot 5 \%$ SDS-PAGE and analysed by Western blot. The inadvertent lysis of tachyzoites was evaluated by determination of $\beta$-galactosidase activity as described by Howe et al. (1997) and Carruthers and Sibley (1999).

\section{Confocal immunofuorescence microscopy}

For immunofluorescence, 5-day cultures of N. caninum from polylysine-coated glass coverslips were fixed in 3\% paraformaldehyde in PBS. After $1 \mathrm{~h}$, the coverslips were rinsed in PBS, permeabilized with PBS $/ 0 \cdot 2 \%$ Triton-X for $30 \mathrm{~min}$ and placed into blocking buffer solution (PBS/3\% $\mathrm{BSA} / 50 \mathrm{~mm}$ glycine) for $16 \mathrm{~h}$ at $4{ }^{\circ} \mathrm{C}$. Samples were rinsed in PBS and incubated with serum against recombinant NcMIC2-like1 (1:100) for $1 \mathrm{~h}$, followed by 3 washes in PBS. The secondary antibody was a goat antirabbit-fluorescein isothiocyanate (FITC) conjugate diluted at 1:100 and nuclear staining was performed with propidium iodide $(0.5 \mu \mathrm{M})$. After extensive washing, the slides were embedded in glycerol and were observed on a confocal microscope (Leica TCS SP4 Laser Scanning Confocal Microscope, Leica Microsystems, Heidelberg, Germany). The images were captured by a $100 \times$ objective in oil immersion. Eight images of $0.6 \mu \mathrm{m}$ from each channel were captured, grouped and processed by the program Image J 1.41 (National Institutes of Health, USA). 

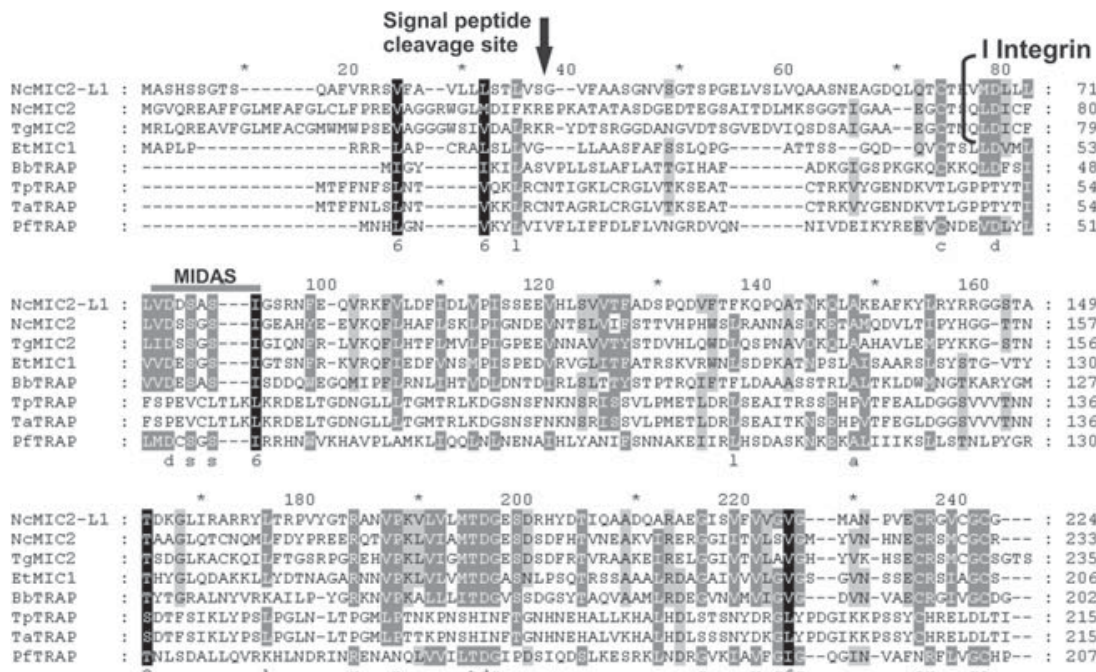

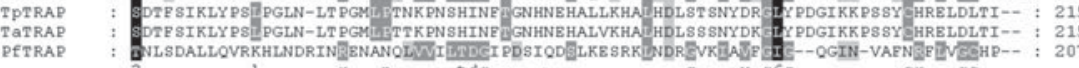

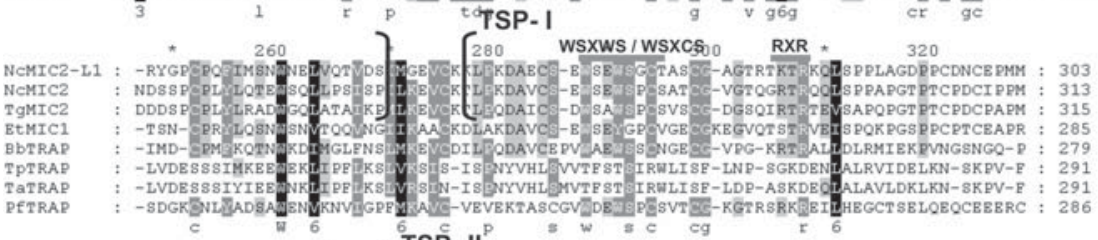

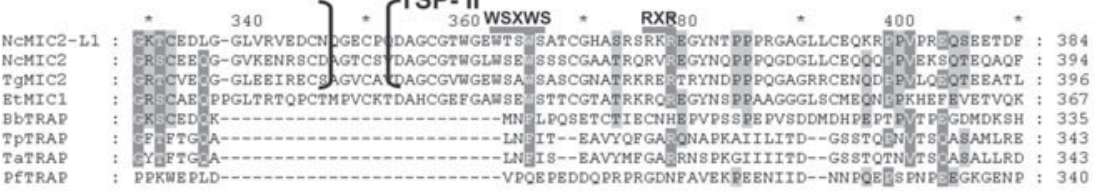

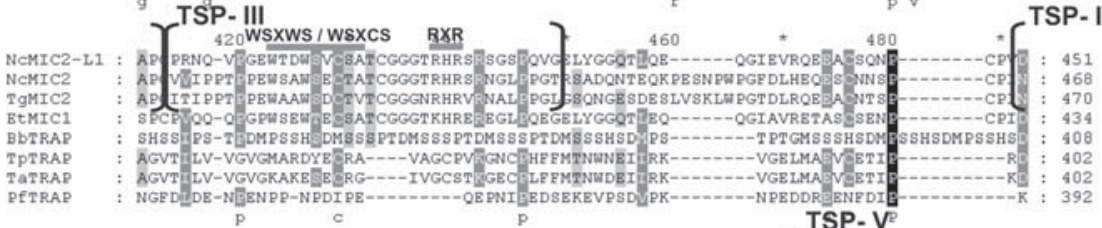

NGMIC2

EtMIC1

BDTRAP

TPTRAP

PETRAP

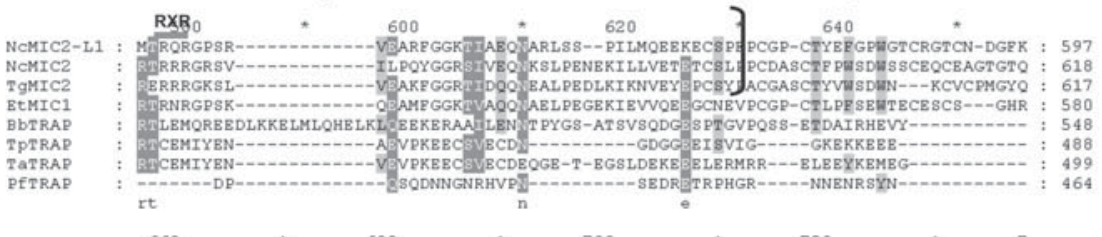

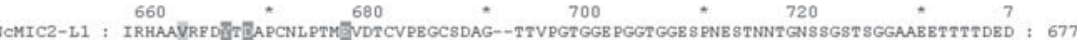

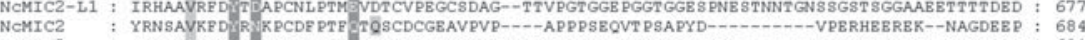

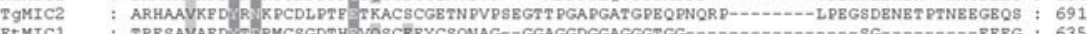

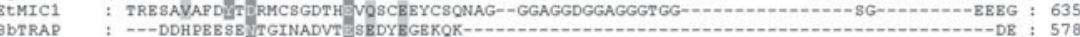

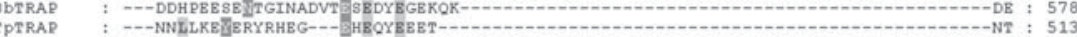
TPTRAP
TATRAP
PETRAP

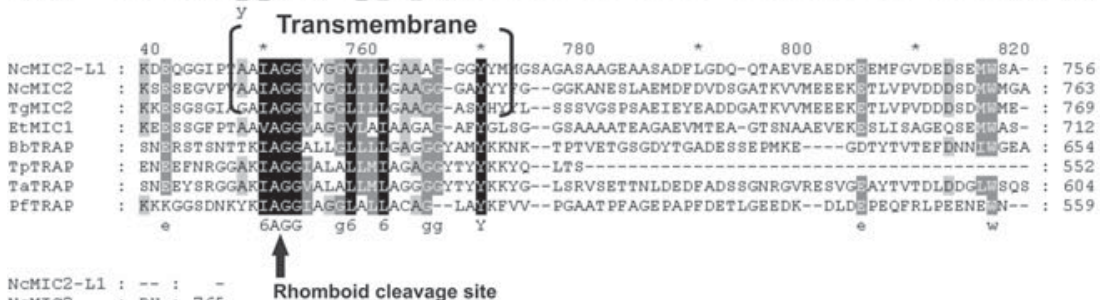

NCAIC2-L1 : - : : - Rhomboid cleavage site

FgMIC2 2010

EtMIC1 $:-1:-$

TPTRAP

$\begin{array}{l:l:l}\text { TaTRAP } & \text { NQ } & 606 \\ \text { PfTRAP } & - & \end{array}$

Fig. 1. For legend see opposite page. 


\section{Invasion assays}

Invasion of Vero cells by $N$. caninum tachyzoites was performed with Vero cell confluent monolayers grown in 24-well flat-bottomed tissue-culture plates (Test Plate, TPP) or 8-well (Lab-Tek Chamber Slide, Nunc) for counting, either by real-time PCR or microscopically, respectively. Freshly purified $N$. caninum tachyzoites $\left(3 \times 10^{5}\right.$ for real-time or $2 \times 10^{5}$ for microscopical assay) were resuspended in $100 \mu \mathrm{l}$ of RPMI1640 with different sera (all diluted $1 / 50)$ and incubated for $1 \mathrm{~h}$ at $37^{\circ} \mathrm{C} / 5 \% \mathrm{CO}_{2}$. The following sera were used: pre-immune (obtained before the first immunization with recombinant NcMIC2-like1), against the recombinant NcMIC2like1 and against tachyzoite protein extract. As controls, rabbit sera against recombinant Trypanosoma cruzi alpha dihydroorotate dehydrogenase enzyme expressed in the same vector pET28 (DHoDH) and no sera (RPMI1640 incubation) were used. These mixtures were added to cell monolayers and allowed to invade for $1 \mathrm{~h}$ at $37^{\circ} \mathrm{C} / 5 \% \mathrm{CO}_{2}$ and subsequently washed with RPMI1640. For the real-time PCR, samples were transferred to microcentrifugation tubes, and DNA was purified according to manufacturer's instructions (Wizard SV Genomic DNA Purification System, Promega). Quantification of the parasites was determined by real time PCR using the primers Nc 5, previously described (CollantesFernandez et al. 2002; Naguleswaran et al. 2003; Ghalmi et al. 2008) but the forward primer was linked to FAM fluorophore Lux (Invitrogen). The experiment was carried out in a Mastercycler ep Realplex (Eppendorf) and the results analysed in the RealPlex (Eppendorf) software. As external standards, DNA corresponding to 1 to $10^{4}$ parasites was used for the standard curve and the samples were calculated by interpolation from this standard curve. In the microscopical assay, monolayers were fixed with methanol for $12 \mathrm{~h}$ and stained with Giemsa for 10 min. For optical microscopy (Leica), 200 cells and tachyzoites detected inside these cells were counted. For both assays the final percentage of invading tachyzoites was calculated as the difference between the average value obtained by the control without serum and the value in each sample divided by the average value obtained by control without serum multiplied by 100 . The invasion assays calculated by microscopic counting was performed in duplicate in 3 independent experiments and the invasion measured

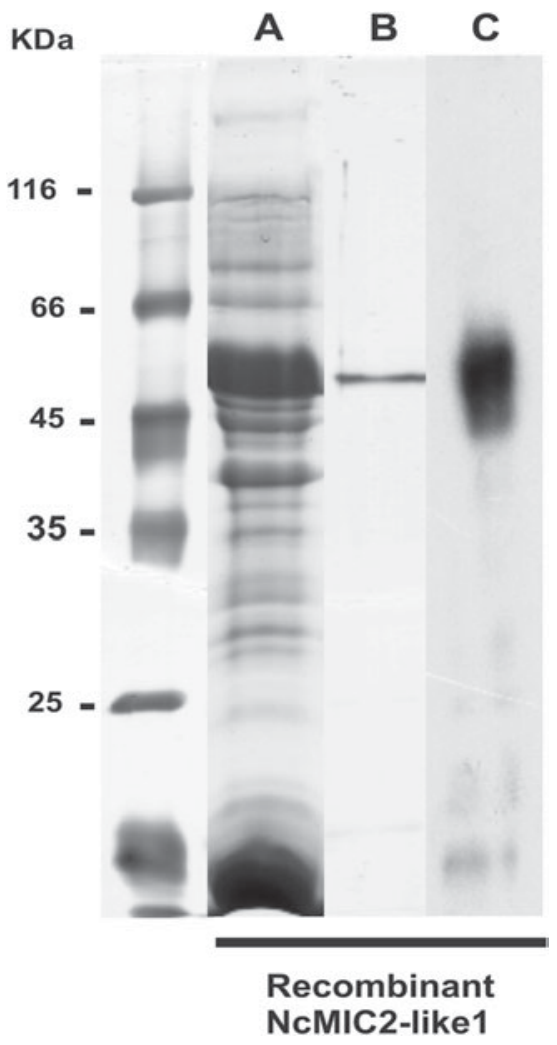

Fig. 2. Recombinant NcMIC2-like1 expression, purification and detection of recombinant. (A) Plasmid pET 28/NcMIC2-like1 was expressed as an insoluble fragment of $52 \mathrm{KDa}$ in E. coli BL21. (B) Ni-Sepharose purified recombinant NcMIC2-like1. (C) 1D Western blot, $1 \mu \mathrm{g}$ of purified NcMIC2-like1 detected with anti-NcMIC2-like1 serum (1/600000, conjugate $1 / 600000)$. Molecular weights are indicated on the left.

by real-time PCR was done in triplicate (with duplicates of them for real-time, $n=6$ ) in 3 independent assays.

\section{Statistical analyses}

The results of invasion assays were expressed as mean \pm standard deviation and analysis of variance (ANOVA) was employed for comparison among different experimental groups. Values among the different samples were compared by the test of Bonferroni, considering statistical significance to be less than $5 \%$. The analyses were performed by the statistical program Graph Pad PRISM 4.0 (Graph Pad, USA).

Fig. 1. Alignment of TRAP proteins from Apicomplexan parasites. MIC2-like1 from Neospora caninum was aligned with the homologues N. caninum MIC2 (AF061273), Toxoplasma gondii MIC2 (AAB63303.1), Eimeria tenella MIC1 (AAD03350), Babesia bovis TRAP (AAS58046), Theileria parva TRAP (EAN31658), Theileria annulata TRAP (CAJ20069) and Plasmodium falciparum TRAP (AAA29777). Brackets indicate the domains, such as I Integrin, 5 Thrombospondins (TSP-s) and the transmembrane region. Arrows indicate the cleavage sites of signal peptide and rhomboids. Grey bars indicate the known regions of each domain related to interaction. 

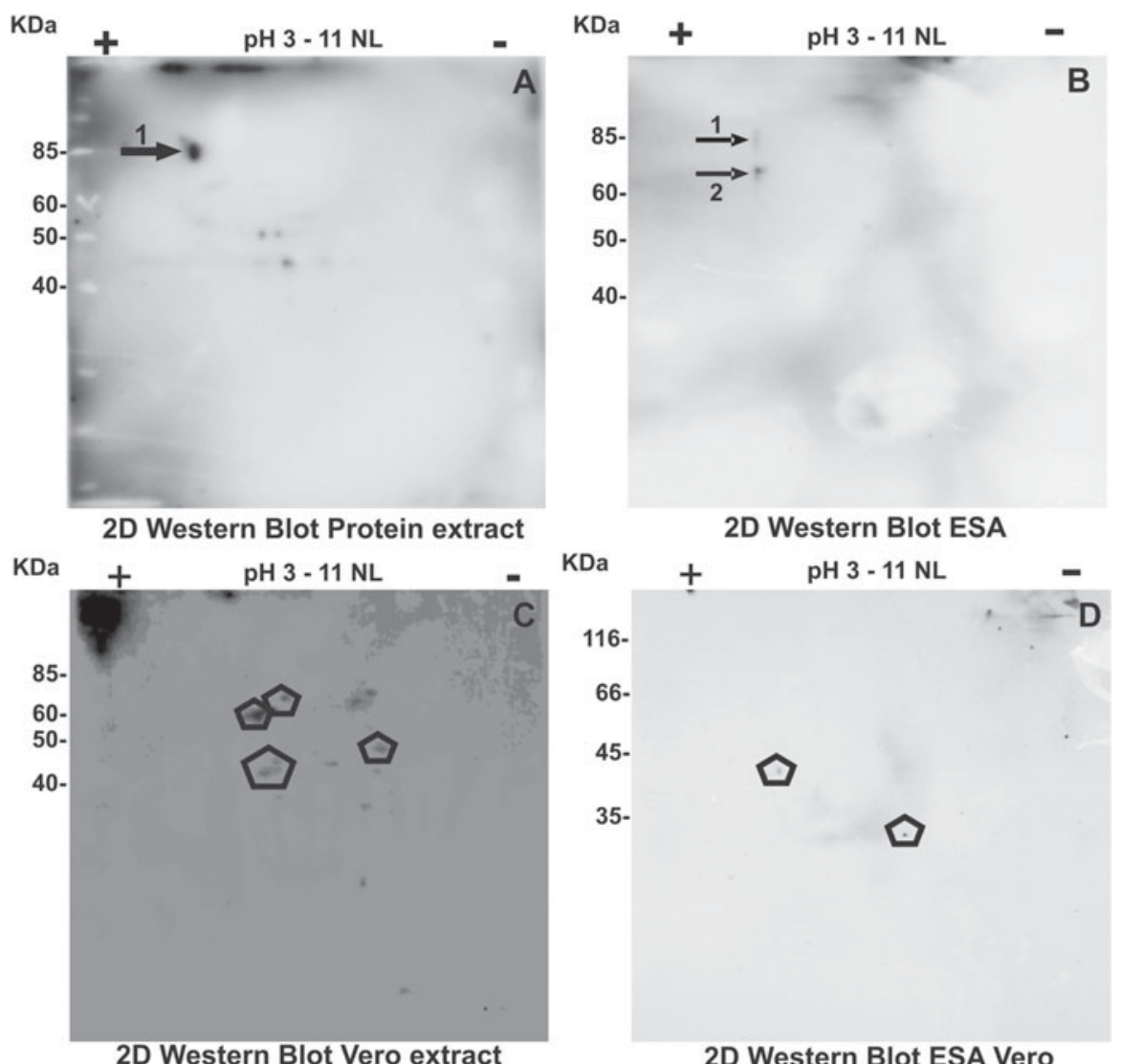

Fig. 3. Detection of native NcMIC2-like1 by 2D Western blot with anti-NcMIC2-like1 serum on Neospora caninum (Nc) tachyzoite protein extract and secreted fraction and on respective Vero controls. (A) Anti-NcMIC2-like1 serum on tachyzoite protein extract. (B) Anti-NcMIC2-like1 serum on Nc secreted fraction. (C) Anti-NcMIC2-like1 serum on Vero protein extract. (D) Anti-NcMIC2-like1 serum on Vero secreted fraction. Arrow 1 represents putative complete form of NcMIC2-like1, arrow 2 represents putative processed form of NcMIC2-like1 and trapezoidal forms represent Vero proteins. The 2D Western blot was made on IPG $13 \mathrm{~cm}$ strips with $\mathrm{pH} 3-11 \mathrm{NL}$ and $12 \cdot 5 \%$ gel. The dilution of anti-NcMIC2-like1 was 1/8000 and conjugate 1/80000 on tachyzoite protein extract and 1/4000 (antiserum) and $1 / 40000$ (conjugate) on secreted fraction.
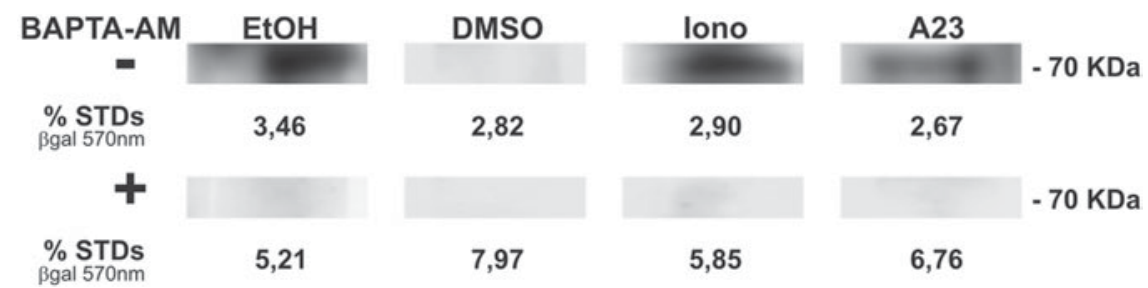

Fig. 4. Calcium-dependent secretion of NcMIC2-like1 secreted from Neospora caninum tachyzoites. Parasites were pre-treated with $100 \mu \mathrm{m}$ BAPTA-A (+) or not (-), and then incubated with ethanol (EtOH, 1\%), DMSO (1\%), ionomycin (Iono, $400 \mathrm{nM}$ ) or A23187 (A23, $400 \mathrm{~nm}$ ) and the supernatants were detected by anti-NcMIC2-like1 (1/2000, conjugate 1/20000). Beta-galactosidase activity at $570 \mathrm{~nm}$ was used as a control for inadvertent parasite lysis, where serial loadings of tachyzoite whole cell lysates were employed for obtaining a curve of the percentage secretion standards (\% STDs). Supernatants of the treatments were compared to the standards and the values are displayed below the Western blot.

\section{RESULTS}

\section{Analysis of the NcMIC2-like1 amino acid sequence}

Full-length NcMIC2-like1 protein was composed of 765 amino acids and the mature protein (without signal peptide) had a predicted molecular weight of $78 \cdot 0 \mathrm{kDa}$ and a pI of $4 \cdot 55$. Like its homologue
NcMIC2 and TgMIC2, NcMIC2-like1 was constituted of a signal peptide, an integrin domain (I domain), 5 thrombospondin-1 (TSP-1) domains, a transmembrane region and a cytoplasmic tail. The NcMIC2-like1 deduced amino acid sequence aligned to NcMIC2 and other Apicomplexa TRAP homologues are shown in Fig. 1. NcMIC2-like1 was 39\% 

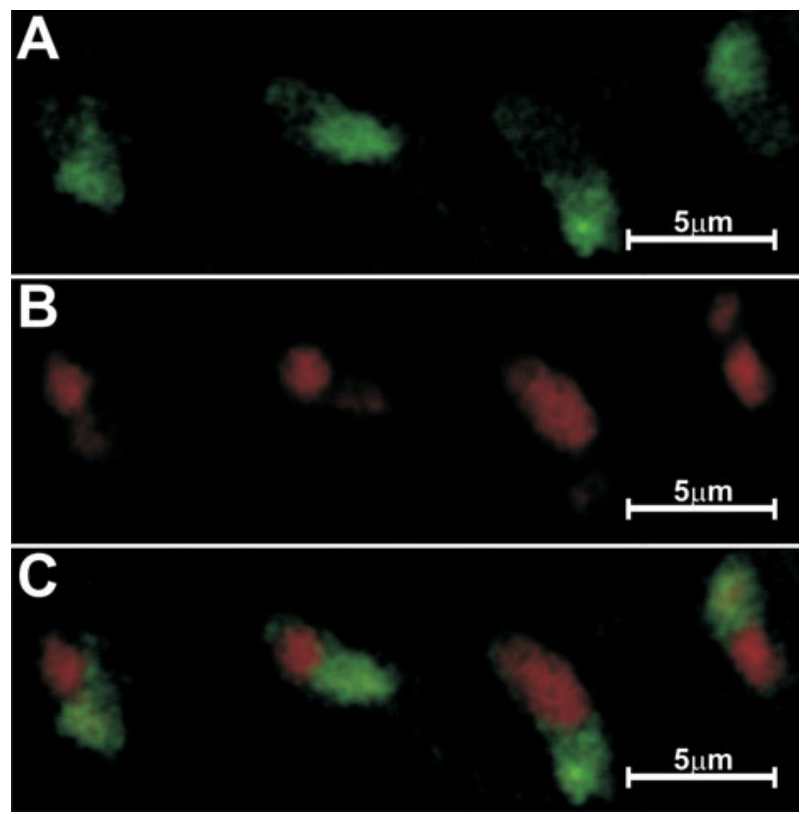

Fig. 5. Immunofluorescent localization of NcMIC2-like1 on Neospora caninum tachyzoites. Tachyzoites were labelled with rabbit anti-NcMIC2-like1 and visualized with goat anti-rabbit FITC (A). The nucleus was visualized with propidium iodide $(\mathrm{B})$ and the merged image is indicated in (C). Scale bar $=5 \mu \mathrm{m}$.

identical (53\% similar) to NcMIC2 and 38\% identical ( $52 \%$ similar) to TgMIC2. The signal peptide had a cleavage site predicted between amino acids 33 and 34 , whereas the putative transmembrane spanning helix was found between residues 687 and 756, near the C-terminus of NcMIC2-like1, which was towards residues 757-756. The adhesive domain (residues 68-247) has homology with several mammalian integrin proteins and was similar to the I domains of other Apicomplexan TRAP homologues. Five repeats, similar to the thrombospondin type 1 motif, were distributed along residues 262 up to 627 constituting the second putative adhesive domain.

\section{Expression of the recombinant NcMIC2-like1 protein}

The expressed recombinant NcMIC2-like1 protein was auto-induced, and under silver staining, detected as a prominent $52 \mathrm{kDa}$ band (Fig. 2, lane A) which was successfully purified (Fig. 2, lane B).

\section{Detection of native NcMIC2-like1}

The $52 \mathrm{kDa}$ recombinant NcMIC2-like1 was recognized by anti-NcMIC2-like1 serum (Fig. 2, lane C) and no reaction was detected on the BL21 protein extract (data not shown). The NcMIC2-like1 protein was predicted to have a molecular weight of $78 \mathrm{kDa}$ and PI of 4.55 whereas the processed form (without transmembrane and cytoplasmatic tail) was predicted to be $72 \mathrm{kDa}$ and PI of $4 \cdot 7$. The native NcMIC2-like1 forms were detected both at $N$. caninum tachyzoite protein extract and at the secreted fraction with $78 \mathrm{kDa}$ (Fig. 3A and B, arrow 1) and at the secreted fraction with $70 \mathrm{kDa}$ (Fig. 3B, arrow 2). In both cases Vero spots were recognized by the antiserum (Fig. 3, $\mathrm{C}$ and D), but none of them coincided with the spots mentioned previously.

\section{Calcium-dependent secretion of NcMIC2-like1}

Similar to the pattern described for TgMIC2 (Carruthers and Sibley, 1999) and NcMIC2 (Lovett et al. 2000), NcMIC2-like1 was secreted (70 kDa) when incubated with ethanol and the calcium ionophores ionomycin and A23183, whilst the process was blocked by treatment with calcium chelator BAP'TA-AM (Fig. 4), indicating that secretion of NcMIC2-like1 requires intracellular $\mathrm{Ca}^{2+}$. The $\beta$-galactosidase activity (indicative of inadvertent lysis of tachyzoites) of the treated samples remained below $10 \%$ in compariston to the control with $100 \%$ of tachyzoite lysate.

\section{Localization of NcMIC2-like1 to micronemes}

NcMIC2-like1 was apically localized when compared to the nucleus (Fig. 5) and only diffuse fluorescence was detected when the serum was used on Vero cells as a control (data not shown), suggesting specific binding.

In vitro invasion assay

Tachyzoite invasion was inhibited when quantified by microscopical assay and real-time PCR (Fig. 6). Anti-NcMIC2-like1 serum inhibited the invasion process by $55 \cdot 5 \%$ in the microscopical assay, while in real-time PCR inhibition was quantified to be $69 \cdot 6 \%$. Anti-tachyzoite protein extract inhibited invasion by $75 \cdot 4 \%$ (microscopical assay) and $85 \cdot 2 \%$ (real-time PCR). Pre-immune serum, the serum obtained before the first immunization with recombinant NcMIC2-like1, inhibited $11.5 \%$ (microscopical assay) and $20 \cdot 2 \%$ (real-time). The vector control serum inhibited the invasion by $16 \cdot 35 \%$ (microscopical assay) and $25 \cdot 5 \%$ (real-time). All values of inhibition with anti-NcMIC2-like1 and anti-tachyzoite protein extract were significant $(P<0.05)$, in contrast to the vector control serum (anti-alfaDHoDH, $P>0 \cdot 05$ ). The results represent 3 independent experiments for the invasion assays and the real-time PCR reactions.

\section{DISCUSSION}

The fact that TgMIC2 (Wan et al. 1997; Barragan et al. 2005) and NcMIC2 (Lovett et al. 2000) 


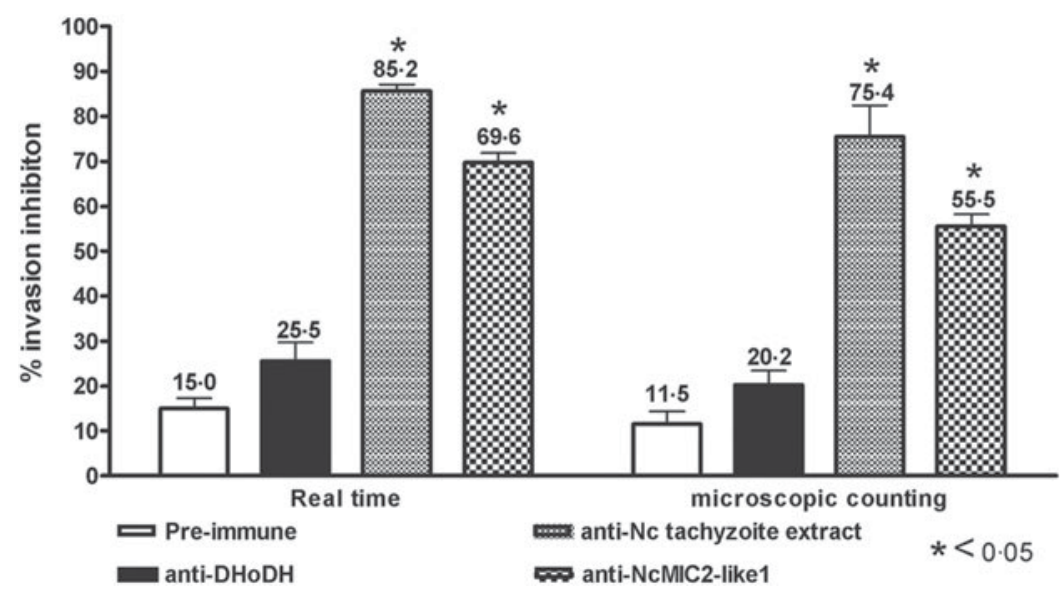

Fig. 6. In vitro invasion assay of Neospora caninum tachyzoites. Tachyzoites were incubated with different sera $(1 / 50)$ for $1 \mathrm{~h}$ before invading Vero cells. The invading tachyzoites were evaluated by microscopical assay and real time PCR. The white columns represent serum from rabbit before the first immunization procedure (pre-immune), black columns antiDHoDH (plasmid control), dotted columns anti-NcMIC2-like1 and grid columns represents anti-Nc tachyzoite extract. ${ }^{*} P<0.05$ in comparison to pre-immune serum.

are closer homologues than NcMIC2 with NcMIC2like1 led us to designate NcMIC2-like1 as a new thrombospondin anonymous related protein. The integrin region in NcMIC2-like1 is located from amino acids 64 to 208 while in NcMIC2 from 73 to 216 and in TgMIC2 from 72 to 215 . This domain is described to act in cell adhesion, migration and in signalling functions (Jonhson et al. 2009) and there is a region known as MIDAS, which is a DXSXS sequence conserved in NcMIC2-like1 as well as in TgMIC2 and NcMIC2 (Lovett et al. 2000). This domain, first detected in mammals, is responsible for the coordinated binding with $\mathrm{Mg}^{2+}$ and $\mathrm{Mn}^{2+}$, mediators of recognition interactions and cell adhesion (Heckmann et al. 2009). Mutations in this domain lead to the loss of ability of interaction of integrin of $T$. gondii with the host cell (Brossier and Sibley, 2005).

In NcMIC2-like1 there are 5 thrombospondins, similar to TgMIC2 and NcMIC2, which are responsible for the recognition of sulphate groups in proteoglycans (Soldati et al. 2001). The thrombospondin domains have several conserved motifs (WSPCSVTCG, RXR and WSXWS) with similar position among homologues TgMIC2, NcMIC2 and NcMIC2-like1 (Lovett et al. 2000).

In the transmembrane region, all homologues have a region of cleavage IAGG, site of rhomboid TgROM 5, essential for parasite release at the end of the invading process (Baum et al. 2008). The cytoplasmic tail of NcMIC2-like1 has 32\% identity and $42 \%$ similarity with $\mathrm{NcMIC} 2$ and $27 \%$ and $46 \%$, respectively, with $\mathrm{TgMIC}$. Compared to the cytoplasmatic tail of TgMIC2, NcMIC2's one has $81 \%$ and $65 \%$ (Lovett et al. 2000). The cytoplasmatic tails of these three proteins have various identical residues, possibly sharing a similar function in the interaction with aldolase, which is the linkage between the actin/myosin motor system and the micronemal protein (Starnes et al. 2006). A conserved tyrosine in TgMIC2 (also present in NcMIC2-like1) is thought to be involved in the interaction with aldolase (Brossier and Sibley, 2005).

The recombinant NcMIC2-like1 was designed based on the integrin and thrombospondin domains, responsible for the attachment and gliding movement of parasite on host cell (Morahan et al. 2008). The expressed recombinant protein had a higher molecular weight $(52 \mathrm{kDa})$ than predicted $(42 \mathrm{kDa})$ when subjected to SDS-PAGE, a fact observed for most TRAP proteins, e.g. in Plasmodium berghei, Plasmodium falciparum (Robson et al. 1997), NcMIC2 (Lovett et al. 2000) and TgMIC2 (Achbarou et al. 1991). This phenomenon is more often observed for proteins with low or high isoelectric points (TRAPs have pI 4-5) and proteins containing a large number of prolines (NcMIC2like1 have 48) which probably lead the protein to adopt a more extended conformation as observed, for example, in collagen and casein (Robson et al. 1997).

The native form of NcMIC2 was described with a molecular weight of $115 \mathrm{kDa}$ and $95 \mathrm{kDa}$ (Lovett et al.2000), much higher than the predicted weight of $78 \mathrm{kDa}$. In contrast, in our work, the native form of NcMIC2-like1 was detected to be approximately $78 \mathrm{kDa}$ and its secreted form $70 \mathrm{kDa}$, which represent values close to the predicted molecular weight for the whole molecule without signal peptide $(78 \mathrm{kDa})$ and after cleavage in the transmembrane region $(72 \mathrm{kDa})$. A wide range of molecular weights of $\mathrm{NcMIC} 2$ and NcMIC2-like1 could be explained by different assumptions, such as several sites of cleavage and different forms of post-translational modifications. Microneme proteins are found in the apical complex, stored in micronemes, which have an important 
function for attachment and initiation of invading processes (Soldati et al. 2001; Cérède et al. 2005; Ravindran and Boothroyd, 2008). Here we have demonstrated that NcMIC2-like1 is mainly located in the apical region of the tachyzoite, possibly in the micronemes, such as demonstrated for NcMIC2 (Lovett et al. 2000), TgMIC2 (Brossier and Sibley, 2005), TgMIC 3 (El-Hajj et al. 2008) and NcAMA 1 (Zhang et al. 2006). To corroborate with microneme localization, the secretion of NcMIC2-like1 was dependent on intracellular $\mathrm{Ca}^{2+}$. The discharge of microneme proteins after treatment with calcium ionophores and the blocking with calcium chelator BAPTA-AM has been described for $T$. gondii (Carruthers and Sibley, 1999; Kawase et al. 2010) and N. caninum (Naguleswaran et al. 2001; Lovett et al. 2000) and was related to regulation of the gliding movement of the parasite (Wetzel et al. 2004).

The methods of measurement of invasion assays in this work consisted of microscopical assay and real-time PCR. As described by Naguleswaran et al. (2003); these different assays showed similar outcomes. In this work, both methods provided very similar results for inhibition of cell invasion; however, real-time PCR had a lower variation and percentages of inhibition were slightly, but significantly, higher than the microscopical assay method. Due to its sensitivity and specificity, the method of real-time PCR has been used for quantification of samples from Toxoplasma, Neospora and Plasmodium (Bell and Ranford-Catrwright, 2002).

The fact that antiserum against NcMIC2-like1, as a single target, inhibited invasion at high levels (up to $69 \%$ ), makes this molecule a potential candidate for inclusion in a multi-component vaccine. In $T$. gondii, selected motifs from crucial proteins for adherence/invasion of TgMIC2, MIC3 and SAG1 have been tested as a chimera in vaccinations (Jongert et al. 2008). The molecular characterization initiated here on NcMIC2-like1 opens the way for more detailed studies on major essential motifs related to cell invasion and on the effectiveness of this protein under in vivo immunization assays.

\section{ACKNOWLEDGEMENTS}

The authors would like to thank Andréa Carla Quiapim (FFCLRP-USP) for the sequencing procedures and the Multi-User Laboratory of Confocal Microscopy (LMMCFMRP-USP- Fapesp 2004/08868-0).

\section{F INANCIAL SUPPORT}

This work was supported by FAPESP (APY, research grant number 2005/53785-9 and LMP, MSc fellowship number 2006/05936-0) and CNPQ (APY Research Grant number 478767/2007-2).
REFERENCES

Achbarou, A., Mercereau-Puijalon, O., Autheman, J. M., Fortier, B., Camus, D. and Dubremetz, J. F. (1991). Characterization of microneme proteins of Toxoplasma gondii. Molecular and Biochemical Parasitology 47, 223-233. doi:10.1016/ 0166-6851(91)90182-6.

Aurrecoechea, C., Brestelli, J., Brunk, B. P., Fischer, S., Gajria, B., Gao, X., Gingle, A., Grant, G., Harb, O. S., Heiges, M., Innamorato, F., Iodice, J., Kissinger, J. C., Kraemer, E. T., Li, W., Miller, J. A., Nayak, V., Pennington, C., Pinney, D. F., Roos, D. S., Ross, C., Srinivasamoorthy, G., Stoeckert, C. J., Jr., Thibodeau, R., Treatman, C. and Wang, H. (2010). EuPathDB: a portal to eukaryotic pathogen databases. Nucleic Acids Research 38, 415-419. doi:10.1093/nar/ gkp941

Barragan, A., Brossier, F. and Sibley, L. D. (2005). Transepithelial migration of Toxoplasma gondii involves an interaction of intracellular adhesion molecule 1 (ICAM-I) with parasite adhesion MIC 2. Cellular Microbiology 7, 561-568. doi:10.1111/j.14625822.2005.00486.x

Baum, J., Gilberger, T. W., Frischknecht, F. and Meissner, M. (2008). Host-cell invasion by malaria parasites: insights from Plasmodium and Toxoplasma. Trends in Parasitology 24, 557-563. doi:10.1016/ j.pt.2008.08.006

Bell, A. and Ranford-Cartwright, L. (2002). Real-time quantitative $\mathrm{PCR}$ in parasitology. Trends in Parasitology 18, 337-342. doi:10.1016/S1471-4922(02)02331-0

Brossier, F. and Sibley, L. (2005). Toxoplasma gondii: microneme protein MIC 2. The International Fournal of Biochemistry \& Cell Biology 37, 2266-2272. doi:10.1016/j.biocel.2005.06.006

Carruthers, V. B. and Sibley, L. D. (1999). Mobilization of intracellular calcium stimulates microneme discharge in Toxoplasma gondii. Molecular Microbiology 31, 421-428. Doi:10.1046/j.1365-2958.1999.01174.x

Cérède, O., Dubremetz, J. F., Soête, M., Deslée, D., Vial, H., Bout, D. and Lebrun, M. (2005). Synergistic role of micronemal proteins in Toxoplasma gondii virulence. Israel Fournal of Experimental Medicine 201, 453-463. doi: 10.1084/jem. 20041672.

Cesbron-Delauw, M. F., Gendrin, C., Travier, L., Ruffiot, P. and Mercier, C. (2008). Apicomplexa in mammalian cells: trafficking to the parasitophorous vacuole. Traffic 9, 657-664. doi: 10.1111/j.16000854.2008.00728.x

Collantes-Fernández, E., Zaballos, A., AlvarezGarcía, G. and Ortega-Mora, L. M. (2002). Quantitative detection of Neospora caninum in bovine aborted fetuses and experimentally infected mice by real-time PCR. Fournal of Clinical Microbiology 40, 1194-1198. doi: 10.1128/JCM.40.4.1194-1198.2002

Daher, W. and Soldati-Favre, D. (2009). Mechanisms controlling glideosome function in apicomplexans. Current Opinion in Microbiology 12, 408-414. doi:10.1016/j.mib.2009.06.008

Dessens, J. T., Beetsma, A. L., Dimopoulos, G., Wengelnik, K., Crisanti, A., Kafatos, F. C. and Sinden, R. E. (1999). CTRP is essential for mosquito infection by malaria ookinetes. The EMBO Fournal $\mathbf{1 8}$, 6221-6227. doi:10.1093/emboj/18.22.6221 
Di Cristina, M., Spaccapelo, R., Soldati, D., Bistoni, F. and Crisanti, A. (2000). Two conserved amino acid motifs mediate protein targeting to the micronemes of the Apicomplexan parasite Toxoplasma gondii. Molecular and Cellular Biology 10, 7332-7341. PMCID: PMC86287

Dubey, J. P., Schares, G. and Ortega-Mora, L. M. (2007). Epidemiology and control of neosporosis and Neospora caninum. Clinical Microbiology Reviews 20, 323-367. doi:10.1128/CMR.00031-06

Dubey, J. P., Hattel, A. L., Lindsay, D. S. and Topper, M. J. (1988). Neonatal N. caninum infection in dogs: isolation of the causative agent and experimental transmission. Fournal of the American Veterinary Medical Association 193, 1259-1263.

E1 Hajj, H., Papoin, J., Cérède, O., Garcia-Réguet, N., Soête, M., Dubremetz, J. F. and Lebrun, M. (2008). Molecular signals in the trafficking of Toxoplasma gondii protein MIC3 to the micronemes. Eukaryotic Cell 7, 1119-1128. doi: 10.1128/EC.00413-07

Friedrich, N., Santos, J. M., Liu, Y., Palma, A. S., Leon, E., Saouros, S., Kiso, M., Blackman, M. J., Matthews, S., Feizi, T. and Soldati-Favre, D. (2010). Members of a novel protein family containing microneme adhesive repeat domains act as sialic acidbinding lectins during host cell invasion by apicomplexan parasites. The Fournal of Biological Chemistry 285, 2064-2076. doi:10.1074/jbc. M109.060988

Gaffar, F. R., Yatsuda, A. P., Franssen, F. F. and de Vries, E. (2004a). A Babesia bovis merozoite protein with a domain architecture highly similar to the thrombospondin-related anonymous protein (TRAP) present in Plasmodium sporozoites. Molecular and Biochemical Parasitology 136, 25-34. doi:10.1016/ j.molbiopara.2004.02.006

Gaffar, F. R., Yatsuda, A. P., Franssen, F. F. and de Vries, E. (2004b). Erythrocyte invasion by Babesia bovis merozoites is inhibited by polyclonal antisera directed against peptides derived from a homologue of Plasmodium falciparum apical membrane antigen 1. Infection and Immunity 72, 2947-2955. doi:10.1128/ IAI.72.5.2947-2955.2004

Ghalmi, F., China, B., Kaidi, R., Daube, G. and Losson, B. (2008). Detection of Neospora caninum in dog organs using real time PCR systems. Veterinary Parasitology 155, 161-167. doi:10.1016/ j.vetpar.2008.04.007

Heckmann, D., Laufer, B., Marinelli, L., Limongelli, V., Novellino, E., Zahn, G., Stragies, R. and Kressler, H. (2009). Breaking the dogma of the metal-coordinating carboxylate group in integrin ligands: introducing hydroxamic acids to the MIDAS to tune potency and selectivity. Angewandte Chemie 48, 4436-4440. doi: 10.1002/anie. 200900206

Hemphill, A., Vonlaufen, N. and Naguleswaran, A. (2006). Cellular and immunological basis of the hostparasite relationship during infection with Neospora caninum. Parasitology 133, 261-278. doi:10.1017/ S0031182006000485

Hoff, E. F., Cook, S. H., Sherman, G. D., Harper, J. M., Fergunson, D. J., Dubremetz, J. F. and Carruthers, V. B. (2001). Toxoplasma gondii: molecular cloning and characterization of a novel $18-\mathrm{kDa}$ secretory antigen, TgMIC10. Experimental Parasitology 97, 77-88. doi:10.1006/expr.2000.4585

Howe, D. K., Mercier, C., Messina, M. and Sibley, L. D. (1997). Expression of Toxoplasma gondii genes in the closely-related apicomplexan parasite Neospora caninum. Molecular and Biochemical Parasitology 86, 29-36. doi:10.1016/S01666851(96)02838-1

Huynh, M. H., Opitz, C., Kwok, L. Y., Tomley, F. M., Carruthers, V. B., Soldati, D. (2004). Trans-genera reconstitution and complementation of an adhesion complex in Toxoplasma gondii. Cellular Microbiology 6, 771-782. doi:10.1111/j.1462-5822.2004.00403.x

Jongert, E., Verhelst, D., Abady, M., Petersen, E. and Gargano, N. (2008). Protective Th1 immune responses against chronic toxoplasmosis induced by a proteinprotein vaccine combination but not by its DNA-protein counterpart. Vaccine 26, 5289-5295. doi:10.1016/ j.vaccine.2008.07.032

Jonhson, M. S., Lu, N., Denessiouk, K., Heino, J. and Gullberg, D. (2009). Integrins during evolution: Evolutionary trees and model organisms. Biochimica et Biophysica Acta 1788, 779-789. doi:10.1016/ j.bbamem.2008.12.013

Kawasaki, P. M., Kano, F. S., Vidotto, O. and Vidotto, M. C. (2007). Cloning, sequencing, expression, and antigenic characterization of rMSP4 from Anaplasma marginale isolated from Paraná State, Brazil. Genetics and Molecular Research: GMR 6, 15-22. PMID: 17278086 .

Kawase, O., Nishikawa, Y., Bannai, H., Igarashi, M., Matsuo, T. and Xuan, X. (2010). Characterization of a novel thrombospondin-related protein in Toxoplasma gondii. Parasitology International 59, 211-216.

doi:10.1016/j.parint.2010.02.001

Keller, N., Naguleswaran, A., Cannas, A., Vonlaufen, N., Bienz, M., Bjorkman, C., Bohne, W. and Hemphill, A. (2002). Identification of a N. caninum microneme protein $(\mathrm{NcMIC} 1)$ which interacts with sulfated host cell surface glycosaminoglycans. Infection and Immunity 70, 3187-3198. doi:10.1128/

IAI.70.6.3187-3198.2002

Lovett, J. L., Howe, D. K. and Sibley, L. D. (2000). Molecular characterization of a thrombospondin-related anonymous protein homologue in Neospora caninum. Molecular and Biochemical Parasitology 15, 33-43. doi:10.1016/S0166-6851(99)00228-5

Menard, R. (2000). The journey of the malaria sporozoite through its hosts: two parasite proteins lead the way. Microbes and Infection 2, 633-642. doi:10.1016/S12864579(00)00362-2

Morahan, B. J., Wang, L. and Coopel, R. L. (2008). No TRAP, no invasion. Trends in Parasitology 25, 77-84. doi:10.1016/j.pt.2008.11.004

Naguleswaran, A., Müller, N. and Hemphill, A. (2003). N. caninum and Toxoplasma gondii: a novel adhesion/invasion assay reveals distinct differences in tachyzoite-host cell interactions. Experimental Parasitology 104, 149-158. doi:10.1016/S00144894(03)00137-1

Naguleswaran, A., Cannas, A., Keller, N., Vonlaufen, N., Björkman, C. and Hemphill, A. (2002). Vero cell surface proteoglycan interaction with the microneme protein $\mathrm{NcMIC}(3)$ mediates adhesion of 
$N$. caninum tachyzoites to host cells unlike that in Toxoplasma gondii. International Fournal for Parasitology 32, 695-704. doi:10.1016/S0020-7519(02)00014-0

Naguleswaran, A., Cannas, A., Keller, N., Vonlaufen, N., Schares, G., Conraths, F. J., Bjorkman, C. and Hemphill, A. (2001). N. caninum microneme protein NcMIC3: secretion, subcellular localization, and functional involvement in host cell interaction. Infection and Immunity 69, 6483-6494. doi:10.1128/IAI.69.10.6483-6494.2001

Putignani, L., Possenti, A., Cherchi, S., Pozio, E., Crisanti, A. and Spano, F. (2008). The thrombospondin-related protein CpMIC1 (CpTSP8) belongs to the repertoire of micronemal proteins of Cryptosporidium parvum. Molecular and Biochemical Parasitology 157, 98-101. doi:10.1016/ j.molbiopara.2007.09.004

Ravindran, S. and Boothroyd, J. C. (2008). Secretion of proteins into host cells by Apicomplexan parasites. Traffic 9, 647-656. doi:10.1111/j.16000854.2008.00723.x

Robson, K. J., Naitza, S., Barker, G., Sinden, R. E. and Crisanti, A. (1997). Cloning and expression of the thrombospondin related adhesive protein gene of Plasmodium berghei. Molecular and Biochemical Parasitology 84, 1-12. doi:10.1016/S01666851(96)02774-0

Soldati, D., Dubremetz, J. F. and Lebrun, M. (2001). Microneme proteins: structural and functional requirements to promote adhesion and invasion by the Apicomplexan parasite Toxoplasma gondii. International Fournal for Parasitology 31, 1293-1302. doi:10.1016/ S0020-7519(01)00257-0

Sonda, S., Fuchs, N., Gottstein, B. and Hemphill, A. (2000). Molecular characterization of a novel microneme antigen in Neospora caninum. Molecular and Biochemical Parasitology 108, 39-51. doi:10.1016/S0166-6851(00) 00200-0
Starnes, G. L., Jewett, T. J., Carruthers, V. B. and Sibley, L. D. (2006). Two separate, conserved acidic amino acid domains within the Toxoplasma gondii MIC 2 cytoplasmic tail are required for parasite survival. The Fournal of Biological Chemistry 286, 45-54. doi: 10.1074/jbc.M606523200

Sultan, A. A., Thathy, V., Frevert, U., Robson, K. J., Crisanti, A., Nussenzweig, V., Nussenzweig, R. S. and Menard, R. (1997). TRAP is necessary for gliding motility and infectivity of Plasmodium sporozoites. Cell 90, 511-522. doi:10.1016/S00928674(00)80511-5

Tomley, F. M., Billington, K. J., Bumstead, J. M., Clark, J. D. and Monaghan, P. (2001). EtMIC4: a microneme protein from Eimeria tenella that contains tandem arrays of epidermal growth factor-like repeats and thrombospondin type-I repeats. International Fournal for Parasitology 31, 1303-1310. doi:10.1016/ S0020-7519(01)00255-7

Wan, K. L., Carruthers, V. B., Sibley, L. D. and Ajioka, J. W. (1997). Molecular characterisation of an expressed sequence tag locus of Toxoplasma gondii encoding the micronemal protein MIC 2. Molecular and Biochemical Parasitology 84, 203-214. doi:10.1016/ S0166-6851(96)02796-X

Wetzel, D. M., Chen, L. A., Ruiz, F. A., Moreno, S. N. and Sibley, L. D. (2004). Calcium-mediated protein secretion potentiates motility in Toxoplasma gondii. Fournal of Cell Science 117, 5739-5748. doi:10.1242/ jcs.01495

Zhang, H., Compaore, M. K., Lee, E. G., Liao, M., Zhang, G., Sugimoto, C., Fujisaki, K., Nishikawa, Y. and Xuan, X. (2006). Apical membrane antigen 1 is a cross-reactive antigen between Neospora caninum and Toxoplasma gondii, and the anti-NcAMA1 antibody inhibits host cell invasion by both parasites. Molecular and Biochemical Parasitology 151, 205-212. doi:10.1016/ j.molbiopara.2006.11.005 